\title{
LITERATURA I PAMIEĆ́ LITERACKIE PODSUMOWANIA RYSZARDA LÖWA
}

Ryszard Löw, Literackie podsumowania polsko-hebrajskie i polsko-izraelskie, red. i oprac. Michał Siedlecki, Jarosław Ławski, posłowie Barbara Olech, Białystok: Katedra Badań Filologicznych „Wschód-Zachód”, Wydział Filologiczny Uniwersytetu w Białymstoku, 2014, 256 s. (rec. Dariusz K. Sikorski, Michał Głowiński).

Działalność pisarska Ryszarda Löwa - eseisty, historyka, krytyka i bibliografa literatury, znawcy literackich związków polsko-żydowskich i polsko-hebrajskich oraz animatora polskojęzycznego życia literackiego w Izraelu, w 1999 r. odznaczonego Krzyżem Orderu Zasługi Rzeczypospolitej Polskiej — od lat znana jest polskim literaturoznawcom. Wielu ludzi nauki, zajmujących się w Polsce problematyką żydowską oraz izraelską, zawdzięcza Löwowi inspiracje do dalszych badań. Jako człowiek-instytucja, w tym długoletni prezes Związku Autorów Piszących po Polsku w Izraelu, Ryszard Löw ma rozległą, erudycyjną wiedzę na temat rozmaitych tekstów, instytucji i ludzi kultury z pogranicza polsko-żydowskiego i chętnie dzieli się nią z polskimi czytelnikami. Już w czasach PRL-u, kiedy odmawiano mu wizy do Polski, Löw systematycznie przesyłał wydawane w Izraelu książki i pisma do najważniejszych bibliotek w kraju, a w kopie odnalezionych w izraelskich archiwach rękopisów książek i listów polskich pisarzy zaopatrywał warszawskie Muzeum Literatury. Znana jest jego współpraca między innymi z Biblioteką Narodową w Warszawie, Instytutem Badań Literackich Polskiej Akademii Nauk, Pracownią Bibliograficzną Instytutu Badań Literackich w Poznaniu, Biblioteką Jagiellońską, Archiwum Emigracji w Toruniu, jak również wieloletnie, aktywne uczestnictwo $\mathrm{w}$ organizowanych przez polskie uniwersytety konferencjach i sympozjach naukowych.

Artykuły i sprawozdania dla polskich czasopism naukowych Löw pisywał już od końca lat 50. (np.: Polonica hebrajskie: bibliografia 1948-1958, Przegląd Orientalistyczny $1959 \mathrm{nr} 4$, s. 407-414) $)^{1}$, natomiast od początku lat 90. opublikował w Polsce i w Izraelu następujące książki: Pod znakiem starych foliantów: cztery szkice o sprawach żydowskich i ksiązkowych (Universitas, Kraków 1993); Hebrajska obecność Juliana Tuwima: szkice bibliograficzne (Hasefer, Tel Awiw 1993); Znaki obecności: o polsko-hebrajskich i polsko-zydowskich zwiqzkach literackich (Universitas, Kraków 1995); Hebrajska obecność Juliana Tuwima: szkice literackie (Oficyna Bibliofilów, Łódź 1996); Rozpoznania: szkice literackie (Księgarnia Akademicka, Kraków 1998).

Najnowsza książka Ryszarda Löwa Literackie podsumowania polsko-hebrajskie i polsko-izraelskie opublikowana została w serii „Przełomy/Pogranicza”, wydawanej od 2012 r. na Wydziale Filologicznym Uniwersytetu w Białymstoku. Książka ta, sta-

${ }^{1}$ W latach późniejszych Ryszard Löw współpracował z tak znaczącymi pismami naukowymi jak „Archiwum Emigracji”, „Pamiętnik Literacki”, „Ruch Literacki” czy „Teksty Drugie”, a także pismami kulturalnymi, takimi jak „Dekada Literacka”, „Twórczość” czy „Więź”. 
nowiąca kontynuację wątków, podejmowanych w poprzednich publikacjach Autora, opatrzona została tytułem sugerującym zamykanie wieloletniego etapu $\mathrm{w}$ dziejach literackich, kulturowych oraz naukowych związków polsko-żydowskich, począwszy od XIX stulecia aż po czasy nam współczesne. Opisywanie świata, który już minął bądź odchodzi w przeszłość, ma nie tylko wartość dokumentacyjną, ale również literacką niewątpliwy dar narracji Ryszarda Löwa sprawia, że prezentowany zbiór naukowych esejów czyta się jak barwną opowieść, której swobodny tok wypowiedzi przywodzi na myśl najlepsze tradycje polskiej gawędy.

Autorzy leksykonu Literatura polska w Izraelu - Karolina Famulska-Ciesielska i Sławomir Jacek Żurek — wyodrębnili trzy kręgi tematyczne zainteresowań Ryszarda Löwa: pierwszy krąg obejmuje literacko-kulturowe pogranicze polsko-żydowskie okresu międzywojennego, a także obszar tworzonego w Izraelu od lat 50. piśmiennictwa polskiego i polskojęzycznego życia literackiego; krąg drugi dotyczy recepcji polskiej literatury w hebrajskim (izraelskim) obiegu czytelniczym; natomiast trzeci odnieść należy do dziejów książki, bibliotek, księgarstwa i bibliofilstwa² .

Wszystkie wskazane przez autorów leksykonu obszary zainteresowań znalazły odzwierciedlenie w trójdzielnej strukturze prezentowanej książki: jej pierwsza część przedstawia wybrane aspekty recepcji krytycznej polskiej literatury w Palestynie, a następnie w utworzonym w 1948 r. państwie Izrael; część druga zawiera szkice poświęcone sylwetkom ludzi, których pasją stały się książki; natomiast trzecia omawia wybrane aspekty życia polskojęzycznego życia literackiego w Izraelu. Polski czytelnik ma okazję zapoznania się z przedstawionym w pierwszej części książki odbiorem czytelniczym takich dzieł jak m.in. Konrad Wallenrod Adama Mickiewicza, Trylogia Henryka Sienkiewicza, Chłopi Reymonta, a także utwory Stefana Żeromskiego oraz Stanisława Brzozowskiego. Wszystkie te dzieła, czytane zarówno po polsku (między innymi przez wywodzących się z Polski członków organizacji syjonistycznej „Haszomer Hacair”), jak i w hebrajskim przekładzie, w kontekście ideologii syjonistycznej traktowane były jako wyraz „literatury pobudzającej do działania” na rzecz utworzenia własnego państwa. Przedmiotem szczególnego zainteresowania Autora stały się wzajemne inspiracje i zapożyczenia pomiędzy literaturą polską, zwłaszcza wielką literaturą romantyczną, a literaturą hebrajską: Löw śledzi biblijne inspiracje w dziele Mickiewicza, na przykład wątek Samsona (,zginę wraz z Filistynami”) w kreacji Konrada Wallenroda; analizuje wpływ, jaki utwory wielkiego romantyka, a szczególnie Konrad Wallenrod oraz Farys, wywarły na twórczość poetów hebrajskich XIX stulecia - m.in. Jehudy Lejba Gordona i Michała Josefa Lebensona — oraz poetów przełomu XIX i XX wieku: Chaima Nachmana Bialika i Saula Czernichowskiego (zauważa przy tym uderzającą zbieżność między poematem Metej hamidbar [Umarli na pustyni] Bialika a Farysem, jak również pomiędzy Sonetami krymskimi a Sonetot Krim Czernichowskiego); omawia Mickiewiczowskie reminiscencje w trójjęzycznej twórczości Icchaka Lejba Pereca, jak również poruszaną w hebrajskiej prasie międzywojnia kwestię żydowskich wątków w biografii i twórczości polskiego wieszcza. Szczególnie istotny okazał się wpływ Mickiewicza na światopogląd Władimira Ze'ewa Żabotyńskiego, rosyjsko-hebrajskiego pisarza, a zarazem przywódcę narodowej frakcji ruchu syjonistycznego. Żabotyński przypisywał Mickiewiczowi ideały syjonistyczne, gdyż autor Konrada Wallenroda pragnienie wskrzeszenia niepodległej Polski wiązał z myślą o stworzeniu państwa żydowskiego na ziemi Izraela.

\footnotetext{
${ }^{2}$ K. Famulska-Ciesielska, S. J. Żurek, Literatura polska w Izraelu. Leksykon, KrakówBudapeszt 2012, s. 107-108.
} 
Obok dzieł polskiego romantyzmu, szczególnie ważnych dla polsko-żydowskiej oraz hebrajskojęzycznej publiczności, Löw przywołuje również kanoniczne utwory polskiej literatury z lat późniejszych. Skupia przy tym uwagę na faktach w Polsce nieznanych, jak na przykład miniony już okres niebywałej popularności dzieł Sienkiewicza (zanim nie wyparła ich hebrajska powieść przygodowa), traktowanych jako „bodziec pobudzający do działania na rzecz odzyskania ojczyzny" (s. 43). Kwestie ideowe legły u podstaw zainteresowania także powieścią Stanisława Brzozowskiego Plomienie (1908), uznaną za pierwszą polską powieść intelektualną, a zarazem kultowe dzieło dla kilku pokoleń lewicowej młodzieży XX stulecia. Fenomenu popularności czytelniczej tej powieści, przerastającej jej recepcję krytyczną, należy upatrywać w zawartych w niej ideach, które okazały się zaskakująco zbieżne z charakterystyczną dla socjalistycznej wersji syjonizmu, a zwłaszcza dla doktryny Arona Dawida Gordona, apoteozą pracy jednoczącej naród. Powieść Brzozowskiego, która wyrażała filozofię pracy jednoczącej wysiłek fizyczny, pracę umysłową i twórczość artystyczną, była krytyką kapitalizmu, tradycjonalizmu i klerykalizmu, a jednocześnie wyrazem poszukiwania dróg naprawy świata. Przyczyniwszy się do krystalizacji koncepcji socjalistycznego syjonizmu „Haszomer Hacair”, odcisnęła piętno na biografii pokolenia Palmachu, walczącego w Palestynie o powstanie państwa. Podobnie sławna w jiszuwie z powodów ideologicznych powieść Chłopi Reymonta, przystająca niejako do doktryny Gordona, a zatem szczególnie popularna w kibucach, posłużyć miała wspieraniu syjonistycznych ideałów pracy na roli.

Włączona w budowę nowego społeczeństwa w Palestynie została również twórczość Stefana Żeromskiego: syjoniści spod znaku „Haszomer Hacair”, a zwłaszcza jego socjalistycznego odłamu, widzieli w Żeromskim pisarza socjalistycznego. W przeciwieństwie jednak do odbioru twórczości Mickiewicza, recepcja prozy Żeromskiego, ograniczona do lat 1936-1959, okazała się nikła i nie odegrała znaczącej roli. Jak zauważa Ryszard Löw, „wcale to jednak nie jest pewne, że była to w pełni rzeczywiście recepcja - hebrajska, a nie proste przedłużenie recepcji polskiej, tyle że po hebrajsku pisanej i do hebrajskiego czytelnika adresowanej" (s. 78).

W pierwszej części książki, obok recepcji polskiej literatury w jiszuwie i w Izraelu, Löw omawia również nieznane bądź mało znane fakty z dziejów polsko-hebrajskich związków literackich i kulturowych na ziemiach polskich: przywołuje epizody z literackiej biografii Juliana Klaczki (właściwie Jehudy Lejba), znanego w historii polskiej literatury jako pierwszy piszący po polsku poeta żydowskiego pochodzenia, a także tłumacz na język hebrajski dzieł Adama Mickiewicza oraz Józefa Korzeniowskiego. Przedstawiając wczesną twórczość hebrajską Klaczki, publikowaną na łamach pism wileńskich, Autor ukazuje go jako pisarza dwujęzycznego, który w oczach hebrajskiej opinii publicznej nie sprostał pokładanym w nim nadziejom. Liczono bowiem, że znający obce języki Klaczko nie porzuci hebrajszczyzny jako narzędzia pracy twórczej, lecz nasyci ją świeckimi treściami, wzbogaci i unowocześni.

Ostatni rozdział pierwszej części poświęcony został postaci badacza literatury Aleksandra Zygi, który „wykonywał oparte na przebogatej osnowie źródłowej [...] prace penetrujące różnorakie zakamarki literatury polskiej" (s. 91) i jako pierwszy badacz w powojennej Polsce — w dysertacji doktorskiej Problem żydowski w twórczości J. I. Kraszewskiego obronionej w 1965 r. na Uniwersytecie Jagiellońskim — podjął temat relacji polsko-żydowskich w polskiej literaturze pięknej.

Druga część Literackich podsumowań polsko-hebrajskich i polsko-izraelskich zawiera sylwetki ludzi książki: bibliofilów i społeczników działających na rzecz hebrajskiej kultury i nauki, a podejmujących swoje wysiłki na ziemiach polskich oraz na 
wschodnich rubieżach Europy. Są to portrety takich postaci jak związany z Białymstokiem lekarz Józef Chazanowicz (1844-1918), który zdołał urzeczywistnić własny projekt powołania do istnienia Biblioteki Narodowej w Jerozolimie; żyjący na przełomie XVIII i XIX wieku drukarz wileński i pierwszy wydawca dzieł Adama Mickiewicza Berko Neumann (1778-1841) oraz Dora Kacnelson (1921-2003) — badaczka polskiej literatury romantycznej, prześladowana w ZSRR z powodów etnicznych.

Literackie podsumowania polsko-hebrajskie i polsko-izraelskie kończą teksty poświęcone polskojęzycznemu życiu literackiemu w Izraelu. W pierwszym tekście trzeciej części Ryszard Löw przypomina dzieje wydawanego w Tel Awiwie ,pisma pogranicza polsko-żydowsko-izraelskiego” (s. 147), czyli rocznika „Kontury” (1988-2006). Począwszy od numeru czwartego, wydanego w roku 1993, aż do końca istnienia tego pisma, Autor pełnił funkcję jego redaktora. W kolejnych szkicach Löw przedstawia nie tylko postacie pisarzy, tworzących polskojęzyczne życie literackie w Izraelu i przez krótszy lub dłuższy czas związanych z „Konturami” (spośród wielu nazwisk wymienić należy m.in. Leo Lipskiego, Idę Fink, Irit Amiel czy Miriam Akavię), ale również pisarzy spoza Izraela, jak Anna Frajlich czy Jadwiga Maurer, a nawet współpracujących z pismem literaturoznawców z kilku polskich ośrodków naukowych oraz krytyków piszących o każdej nowej edycji telawiwskiego rocznika. Część książki dotycząca „Konturów” zawiera, uzupełniane informacjami bibliograficznymi, szkice portretowe takich postaci polskojęzycznego życia literackiego w Izraelu, jak Andrzej Sycz, Paweł Glikson, Łucja Pinczewska-Gliksman, Jozef Bau, Filip Istner, Natan Gross, Zygmunt Frankel, Anita Wolfstein, Maria Lewińska i księgarz Jan Fok, a także hebrajskich pisarzy i thumaczy, którzy pisali o polskiej literaturze bądź ją tłumaczyli, jak Dow Sadan czy Joram Bronowski. Do tej części książki, podobnie jak do części drugiej, można odnieść słowa Sary Grudzińskiej: „większość wypowiedzi krytycznych Löwa nosi właśnie charakter interwencyjny: ratuje przed niebytem tych, którzy tymczasem zmarli i zostali zapomniani"3. Pisząc na temat krytycznego odbioru pisma w Izraelu i za granicą, Löw podkreśla zarazem jego rolę dokumentacyjną; przytacza przy tym opinię recenzenta paryskiej „Kultury”, który zauważa, że „od początku swojego istnienia «Kontury» miały być literackim dokumentem odrębnego i samodzielnego, choć niezbyt licznego środowiska pisarskiego" (s. 152).

Zamykające książkę posłowie Barbary Olech Ryszard Löw - krakowianin z Tel-Awiwu, w którym autorka przedstawia biografię Ryszarda Löwa oraz jego ogromne zasługi dla polskiej i żydowskiej kultury, słusznie stawia go w roli jednego z bohaterów prezentowanej książki. Jak bowiem pisze Zbigniew Pakuła, „Ryszard Löw od bardzo wielu lat przywołuje ślady polskości. W tym znakomitym, profesjonalnym uporze przypomina rzemieślnika w najlepszym tego słowa znaczeniu. Dba o każdy detal, fakt, sprawę mało znaną. I kiedy już wykona swoją robotę (nazywa ją wytuskiwaniem), odsłania się przed nami dzieło o szerokich horyzontach, bogatych materiałowo, za którym stoi, nie bójmy się użyć tego słowa, miłość do języka polskiego, do polskiej kultury"^4.

Należy wyrazić nadzieję, że książka Literackie podsumowania polsko-hebrajskie i polsko-izraelskie nie jest jeszcze zwieńczeniem dorobku jej Autora, lecz zwiastunem kolejnych, równie ważnych poznawczo i fascynujących opowieści o ludziach i książkach.

Beata Tarnowska (Uniwersytet Warmińsko-Mazurski)

\footnotetext{
${ }^{3}$ S. Grudzińska, Waga pamięci, Bibliotekarz Podlaski 2015 nr 30, s. 202.

${ }^{4}$ Z. Pakuła, Izrael.pl, Miasteczko Poznań 2014 nr 3-4; http://www.miasteczkopoznan.pl [dostęp: czerwiec 2016].
} 